\title{
Henrique Dumont: how a traumatic brain injury contributed to the development of the airplane
}

\author{
Henrique Dumont: como um traumatismo cranioencefálico contribuiu para o \\ desenvolvimento do avião
}

Zeferino Demartini Jr',2, Luana A. Maranha Gatto², Roberto Oliver Lages², Gelson Luis Koppe

\begin{abstract}
The life and death of Henrique Dumont (1832-1892) is little known, being usually remembered as Alberto Santos-Dumont's father. This report describes the history of this Brazilian engineer, also known as the King of Coffee, who achieved enormous business success and fortune in the late nineteenth century. In 1890, during the inspection of his farm, the world's largest coffee plantation at that time, he fell from a carriage, which left him a hemiplegic. This forced him to sell the farm and move to France for treatment. Before his death two years later, he gave his 18-year-old son bits of advice, and distributed his inheritance, which allowed Alberto to study in Paris and finance his experiments that would culminate in the development of the airplane. The diagnostic and therapeutic possibilities are also discussed.
\end{abstract}

Keywords: History; medical history taking; craniocerebral trauma; brain injuries, traumatic; trauma, nervous system.

RESUMO

A vida e especialmente a morte do brasileiro Henrique Dumont (1832-1892) são pouco conhecidas, sendo geralmente lembrado como pai de Alberto Santos Dumont. Relatamos a história deste engenheiro que obteve enorme sucesso empresarial no final do século XIX, sendo denominado Rei do Café. Em 1890, durante a inspeção da sua fazenda, maior cafeicultura do mundo na época, caiu da charrete e ficou hemiplégico. Isso o fez vender a fazenda e buscar tratamento na França, trazendo o primeiro automóvel do Brasil ao retornar. Antes de morrer dois anos após o acidente, deu valorosos conselhos e distribuiu sua herança ao filho Alberto, então com dezoito anos de idade, que pôde assim estudar em Paris e financiar seus experimentos que culminariam no desenvolvimento do avião. São discutidas e contemporizadas as possibilidades diagnósticas e terapêuticas relacionadas ao déficit neurológico.

Palavras-chave: História; anamnese; traumatismos craniocerebrais; lesões encefálicas traumáticas; traumatismos do sistema nervoso.

While the story of Alberto Santos-Dumont and his inventions are relatively well studied, the life - and especially the death - of his father, Henrique Dumont, is little known. This report describes the latter's successful trajectory, which gave stability to his son, enabling him to study and develop the airplane.

\section{Biography}

Henrique Honoré Dumont was born on July 20, 1832, the second of three children, in the current city of Diamantina, Minas Gerais, Brazil-the world's largest diamond producer at that time $e^{1,2,3}$. He was the son of Eufhrazie
Françoise Honorée and François Honoré Felix Dumont, who were married in France, and moved to Brazil in 1828, looking for precious stones for family jewelry ${ }^{1,2,3}$. With the discovery of diamonds in South Africa, prices fell, hurting the business, and François, possibly shaken emotionally, got sick and died young in $1842^{1}$. Henrique's godfather sent him to the School of Arts and Crafts in Paris, the equivalent of the Faculty of Engineering, where he graduated at age 21 (Figure 1$)^{1}$.

Returning to Brazil, Henrique worked in Ouro Preto and on September 6, 1856, married Francisca de Paula Santos, the daughter of a famous nobleman ${ }^{1}$. On June 25,

${ }^{1}$ Universidade Federal do Paraná, Divisão de Hemodinâmica, Curitiba PR, Brasil;

${ }^{2}$ Pontifícia Universidade Católica do Paraná, Hospital Universitário Cajuru, Divisão de Neurocirurgia, Curitiba PR, Brasil;

${ }^{3}$ Hospital Vita Curitiba, Departamento de Neurocirurgia, Curitiba PR, Brasil.

Zeferino Demartini Jr. (iD) https://orcid.org/0000-0002-0683-5418

Correspondence:Zeferino Demartini Jr.; Hospital Universitário Cajuru - PUCPR, Departamento de Neurocirurgia; Avenida São José, 300 ; 80050 -350 Curitiba PR, Brasil; E-mail: demartiniz@gmail.com

Conflict of interest: There is no conflict of interest to declare.

Received 24 June 2018; Accepted 29 August 2018. 


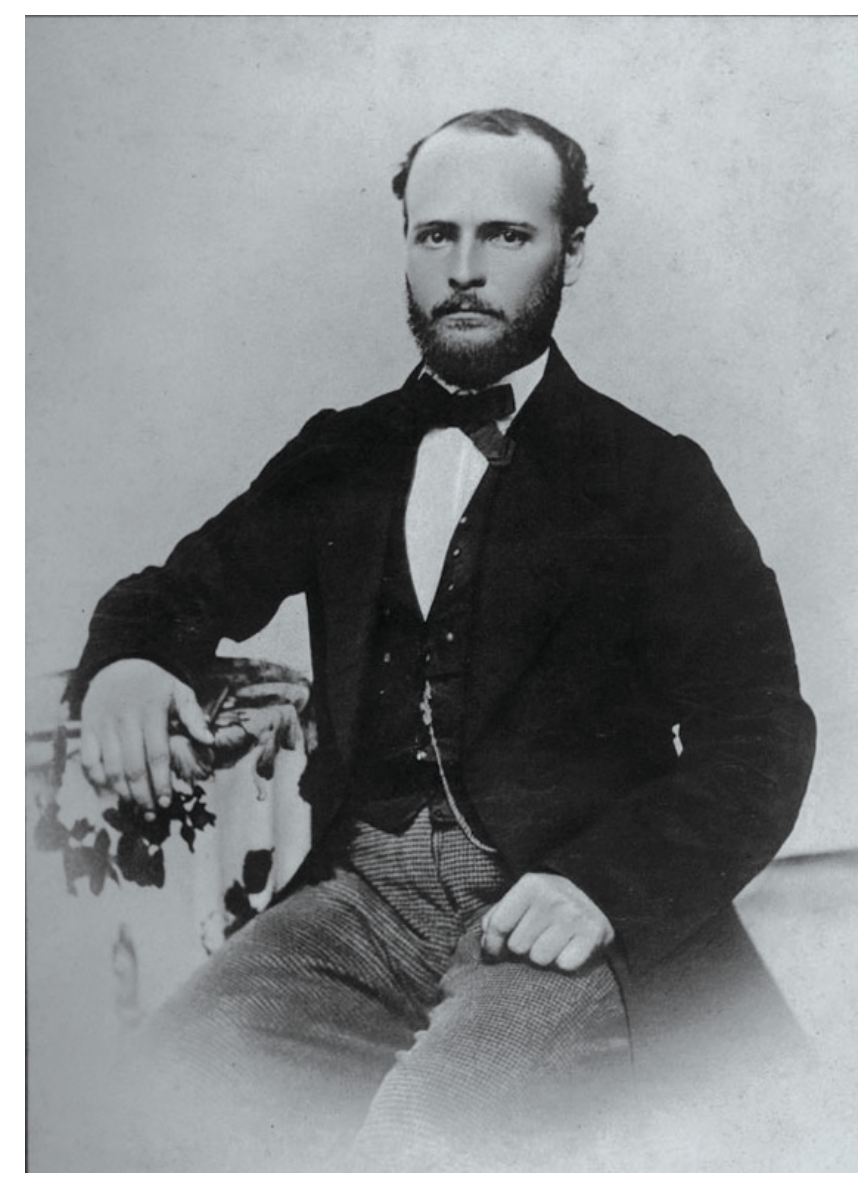

Figure 1. Henrique Dumont graduated from the School of Arts and Crafts in Paris, which was the equivalent of the Faculty of Engineering.

1867, Henrique signed a contract with Joaquim Saldanha Marinho to build a steamboat, which was launched by Emperor Dom Pedro II on the São Francisco River on February 2, $1871^{1}$. In 1872, Henrique became the engineer on the Central Railroad of Brazil, constructing the Dom Pedro II railway. He moved with his wife and five children to a farm in Cabangu, which today is in Santos Dumont municipality, Minas Gerais ${ }^{1}$. There, Alberto Santos-Dumont was born on July 20, 1873-on Henrique's $41^{\text {st }}$ birthday - the sixth of eight children ${ }^{1}$. After the construction ended, the family moved to Henrique's father-in-law's coffee farm in Rio das Flores, Rio de Janeiro, where Alberto was baptized on February 20, $1877^{1}$.

Due to poor agricultural production, Henrique moved to São Paulo where, in 1879, he bought a coffee farm in São Sebastião do Ribeirão Preto ${ }^{1,4}$. In 1883, the Mogiana railroad was inaugurated, facilitating the development of the region and the bringing in of immigrants to replace the slave labor force. After successive land acquisitions, in 1887 Henrique formed the largest agricultural farm in Brazil, with 5.7 million coffee plants, and was called the "King of Coffee". On October 10, 1888, Henrique signed an agreement connecting the Dumont farm to the railway, built around $100 \mathrm{~km}$ of

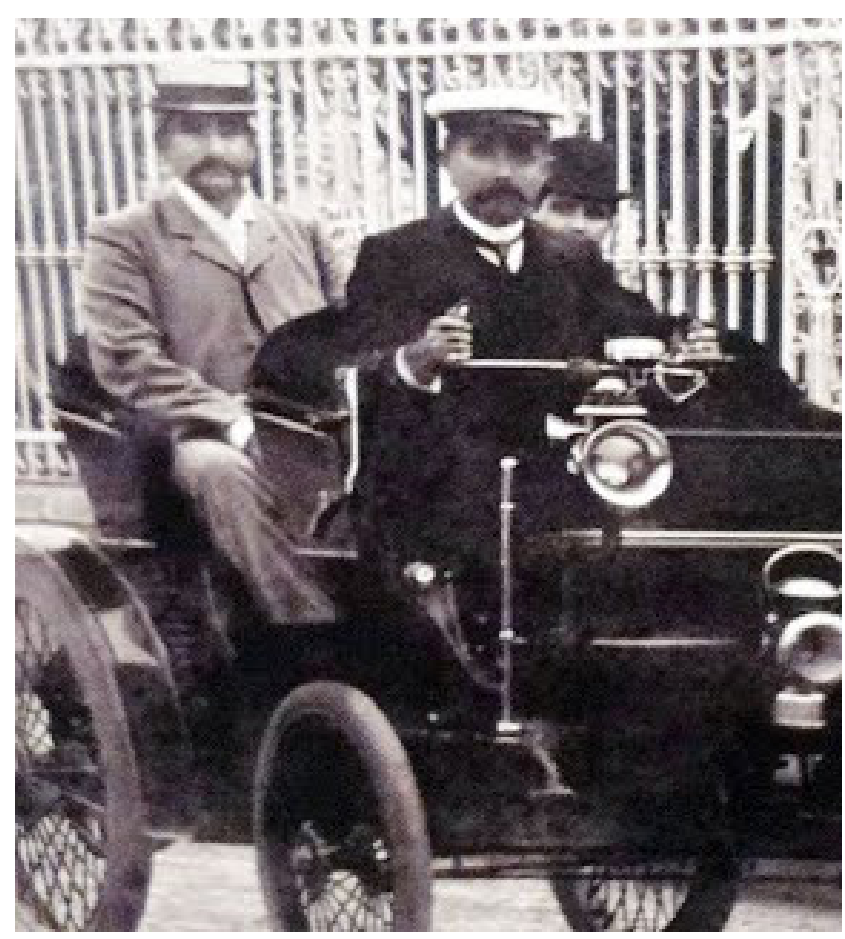

Figure 2. Santos-Dumont driving the first Brazilian gasoline car, bought by his father Henrique in 1891.

track, and imported seven locomotives and 40 wagons from England $^{1,5}$. Alberto spent his childhood on this farm, being taught by his sister Virginia ${ }^{1}$.

In December 1890, during a farm inspection, Henrique fell from a carriage, broke his arm and hit his head, which left him a hemiplegic ${ }^{1,4}$. He then sold the farm to the Companhia Melhoramentos do Brasil and, on April 6, 1891, he traveled to France looking for more advanced Medicine and a cure, staying at the baths of Lamalou-les-Bains ${ }^{1}$. During this trip, Alberto visited the Industrial Pavilion at the Paris International Exposition, coming into contact with technological innovations such as the cinema, the gramophone and, especially, the gas combustion engine ${ }^{6,7}$. On November 21, Henrique returned to Brazil ${ }^{8}$, bringing a 3.5-horsepower Peugeot, the first gasoline car in Brazil (Figure 2) ${ }^{9}$. At 18 years of age, on February 12, 1892, Alberto was emancipated by his father, and received a small fortune in titles ${ }^{6}$. His father advised: "I still have a few years to live, I want to see how you conduct yourself: go to Paris, the most dangerous place for a boy, let's see if you become a man; I prefer you not to become a doctor; the future of the world is in mechanics. You do not have to work; I will leave you the necessities to live".

With 60-year-old Henrique's health worsening, he tried to return to France but died in Rio de Janeiro on August 30, 1892. This was a severe emotional blow to young Alberto, but following the advice of his father, he moved to Paris in the same year, dedicating himself to his studies and initiating experiments with balloons. These led him to develop, in 1906, the mythical 14-Bis, the first "heavier-than-air" aircraft, in the history of mankind, to fly ${ }^{1}$. 


\section{DISCUSSION}

This case illustrates the transition period from olden days low-energy trauma to high-energy traumatic brain injury associated with the development of cars and airplanes. Although the time elapsed between Henrique's fall and his symptom is not clear, a diagnosis of traumatic brain injury followed by a permanent deficit in the hemibody probably indicates brain injury due to cerebral contusion. Acute subdural hematomas causing cerebral hemisphere compression are usually associated with brain swelling, coma, intracranial hypertension and death in the absence of treatment. A cranial fracture, especially in the temporal region, can damage the middle meningeal artery causing epidural hemorrhage, which is potentially fatal without surgical evacuation, but is an unlikely etiology in the case in question. The possibility of ischemic or hemorrhagic stroke followed by a fall may also be considered, which may still confuse the diagnosis nowadays. If the deficit developed late, it could be related to a chronic subdural hematoma or even traumatic arterial dissection causing secondary thrombosis or embolism. It is important to remember that there were no diagnostic imaging examinations, which began in the $20^{\text {th }}$ century with $x$-rays, angiography, pneumoencephalography, computed tomography and magnetic resonance. Likewise, neurological surgeries were not performed at that time, and it is interesting to note that today, a patient presenting with a motor deficit due to encephalic trauma and intracranial hematoma is usually operated upon, reversing deficits in some cases of early hospital admission. However, the advent of a chronic deficit interrupted Henrique's labor activities and forced the family to sell their property. Henrique's reflective period after the accident culminated in advice on his son's future, while the early distribution of the inheritance allowed Alberto to study and finance his experiences ${ }^{1}$.

Alberto's father had a fundamental role in his son's development once, having perceived Alberto's fascination for machines, he directed his studies toward mechanics, physics, chemistry and electricity, different to that of his brothers ${ }^{1}$. Transposing Henrique's accident to modern days, a huge farm would probably be inspected by helicopter, whose accidents are generally fatal; thus the sudden death of the patriarch could have triggered a war for succession and inheritance, possibly disrupting the development of a promising inventor.

\section{References}

1. Pinheiro L. Henri Dumont: Os feitos extraordinários de um grande diamantinense ignorado por seu povo. 2011 [cited 2018 May 15] Available from: http://www.altitudemaxima.com.br/noticias/ henridumont-osfeitosextraordinariosdeumgrandediamantinenseign oradoporseupovo

2. Henrique Honorée Dumont. Geni.com. 2011 [cited 2018 May 15]. Available from: https://www.geni.com/people/HenriqueDumont/6000000015810266465

3. François Honoré Felix Dumont (I3645). Nossa Gente. 2011 [cited 2018 May 15]. Available from: http://www.nggenealogia.com.br/tree/ individual.php?pid $=\mid 3645 \&$ ged $=$ php.ged

4. Klintowitz J. Santos Dumont: as asas do homem. Superinteressante. 2016 Oct 31[cited 2018 May 15]. São Paulo: Editora Abril. Available from: https://super.abril.com.br/historia/santos-dumont-as-asasdo-homem/
5. Pestana FR. A Província de São Paulo, 1888 Oct 12 [cited 2018 May 29]. Available from: http://acervo.estadao.com. br/pagina/\#!/18881012-4059-nac-0001-999-1-not/busca/ Henrique+Dumont

6. Fenske EK. Alberto Santos-Dumont: eu naveguei pelo ar. Templo Cultural Delfos, 2011 [cited 2018 May 27];8. Available from: https:// www.elfikurten.com.br/2011/11/alberto-santos-dumont-eunaveguei-pelo.html

7. Dumont AS. Meus balões: autobiografia. São Paulo: LeBooks; 2018.

8. Carneiro M,Araujo JF, Mendes E. Entradas do dia 21. Gazeta Notícias (Rio de Janeiro). 1891 [cited 2018 May 30] Nov 22. Available from: http://memoria.bn.br/DocReader/docreader. aspx?bib=103730_03\&pasta=ano\%20189\&pesq=Henrique\%20dumont

9. Costa FH. Santos-Dumont: história e iconografia. 2nd ed. Rio de Janeiro: Incaer; 1990. 